\title{
Effects of the Long-acting Somatostatin Analogue Octreotide on Abomasal Function and Plasma Level of Insulin and Glucagon in Sheep
}

\author{
By K. Holtenius
}

Department of Clinical Nutrition, Faculty of Veterinary Medicine, Swedish University of Agricultural Sciences, Uppsala Sweden.

\begin{abstract}
Holtenius, K.: Effects of the long-acting somatostatin analogue octreotide on abomasal function and plasma level of insulin and glucagon in sheep. Acta vet. scand. 1994, 35, 235-241. - The effects of the long-acting somatostatin analogue octreotide were studied in sheep. Octreotide was given subcutaneously at a dose of $0.75 \mu \mathrm{g} / \mathrm{kg}$ bodyweight and, as a control, $0.9 \%$ saline solution was injected in a change-over design. Octreotide inhibited abomasal acid secretion and retarded the turnover time of digesta through the abomasum. The plasma levels of insulin and glucagon decreased due to the octreotide injection, while the plasma glucose level was not affected. The effects of octreotide lasted for 3-4h. There were no significant effects of the saline injection. The effects of octreotide showed similarities with results from previous studies on monogastric species.
\end{abstract}

inhibitory effects; abomasal pH; abomasal fluid turnover time; glucose production.

\section{Introduction}

Somatostatin, a peptide hormone first detected in the ovine hypothalamic tissue, has mainly inhibitory effects that block the release or antagonize the actions of many other hormones and neurotransmitters. It inhibits the release of growth hormone from the pituitary and insulin and glucagon from the pancreas (Brazeau et al. 1973, Koerker et al. 1974). Within the gastrointestinal tract it is a potent inhibitor of basal and stimulated gastrin, pepsin and gastric acid secretion in many monogastric species (Arimura \& Fishback 1978, Wynick et al. 1989). Somatostatin has also been suggested to be associated with the inhibition of gastric motility of the preruminant calf (Sissons et al. 1988, Bell et al. 1981). It has been identified in multiple locations of the mamalian body. More than $90 \%$ of the natu- rally occurring somatostatin is found in the endocrine $\delta$ cells of the pancreas and in the stomach of monogastric species. In sheep, somatostatin has been shown to be present mainly in the pancreas and in the antral part of the abomasum. The rumen and the reticulum contained comparatively low concentrations of somatostatin (Darvodelsky et al. 1988). Nutrients such as amino acids and glucose stimulate the somatostatin release in monogastric species (Schusdziarra et al. 1978, Grill et al. 1984). In dairy cows, feeding gave rise to somatostatin release (Svennersten et al. 1989).

Extensive studies of the effects of administration of exogenous somatostatin on different, mainly monogastric, species have been performed during the 2 last decades. The clinical applications of somatostatin are limited by its 
short half-life, about 2 min. The long-acting somatostatin analogue octreotide mimics many of the effects of native somatostatin. There are several therapeutic applications of octreotide in man, including treatment of ketoacidosis and various gastrointestinal disorders (Aarsen et al. 1987, Lamers 1987). The potential usefulness of octreotide in ruminant medicine has not yet been investigated.

The aim of the present experiment was to study the effects of octreotide on the abomasal function and on the plasma level of insulin and glucagon in sheep.

\section{Materials and methods}

Four mature non-lactating, non-pregnant sheep of the Fine Wool Breed were used. They were fitted with a cannula in the abomasum about $10 \mathrm{~cm}$ from the pylorus. The cannula was made of brass and the i.d. was $6 \mathrm{~mm}$. The surgery was performed under general anaesthesia (sodium pentobarbitone) about 2 months before experimentation. The sheep, weighing $46-57 \mathrm{~kg}$, were housed together in a large pen except during experimental days when they were kept individually in cages. They were fed hay ad libitum at $07.00 \mathrm{~h}$ and $15.00 \mathrm{~h}$. Water was available ad libitum. Morning feeding was omitted on the day of an experiment.

The sheep were randomly divided into 2 groups. One group got a subcutaneous injection with $0.75 \mu \mathrm{g} / \mathrm{kg}$ body weight of octreotide (Sandostatin, Sandoz, Basel, Switzerland) and the other got a subcutaneous injection with $0.5 \mathrm{ml}$ physiological $0.9 \%$ saline solution. One week later the experiment was repeated in a cross over-design. Thus both groups were subjected to both treatments. Venous blood was collected in $\mathrm{K}_{3}$-EDTA coated tubes by means of a previously inserted catheter in one of the jugular veins at $08.00 \mathrm{~h}$, prior to the injection, and $1,2,3,4,5$, and $6 \mathrm{~h}$ after injection. The blood was kept in pre-chilled tubes and centrifuged at $4^{\circ} \mathrm{C}$. The plasma was separated and stored at $-20^{\circ} \mathrm{C}$. Concentrations of immuno reactive insulin and glucagon were measured in duplicate in $\mathrm{K}_{3}$-EDTA plasma with $500 \mathrm{kal}$ likrein units of aprotinin (Trasylol, Bayer, Leverkusen, Germany) per ml. Insulin was determined by radioimmunoassay using an assay kit (Pharmacia RIA 100, Pharmacia Diagnostics AB Uppsala, Sweden). Glucagon was measured with an antibody which is specific for pancreatic glucagon (K 5563, NOVO Nordisk A/S, Bagsværd, Denmark). The plasma was extracted and analysed as recommended by NOVO Nordisk A/S with the exception that a double antibody (sheep antirabbit antibody, Pharmacia Diagnostics, Uppsala, Sweden) was used as decanting suspension and the precipitate was measured for bound glucagon.

Cobalt-EDTA, which has been shown to be a suitable marker for estimations of gastro-intestinal fluid flow was prepared according to Udén et al. (1980). Five hundred mg of cobaltEDTA dissolved in $25 \mathrm{ml}$ water was injected directly into the abomasum via the cannula $2 \mathrm{~h}$ after the octreotide or saline injection. Samples from the abomasal contents, about $10 \mathrm{ml}$, were withdrawn $20,28,36,44,52,60,68$ and $76 \mathrm{~min}$ after the cobalt-EDTA injection. The samples were immediately centrifuged and the supernatant fraction analysed for cobalt at $240.7 \mathrm{~nm}$ in an atomic absorption spectrophotometer (Perkin-Elmer 4000). The rate of passage of the abomasal fluid was estimated from the slope when the log concentration of cobalt was plotted versus time as described for the rumen by Warner \& Stacy (1968). Furthermore, samples from abomasal contents were withdrawn according to the same protocol as for the blood samples and $\mathrm{pH}$ immediately measured.

Values are presented as means with standard 


\section{$-\bigcirc-$ Octreotide $\quad-\Delta-$ Saline}

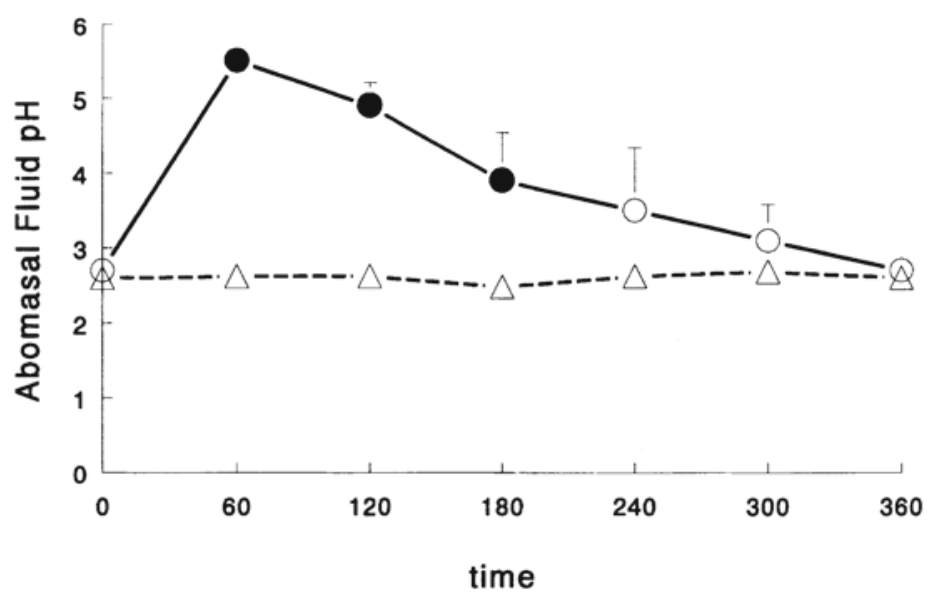

Figure 1 . The $\mathrm{pH}$ of abomasal fluid of sheep subcutaneously injected with octreotide $(0.75 \mu \mathrm{g} / \mathrm{kg}$ bodyweight $)$ or saline $(0.9 \% 0.5 \mathrm{ml})$. Filled symbols represent a significant difference of at least $\mathrm{p}<0.05$ from the pre-injection value. Data are given as means of 4 sheep and vertical bars represent standard error of mean.

$$
\text { - - Octreotide } \quad-\triangle-\text { Saline }
$$

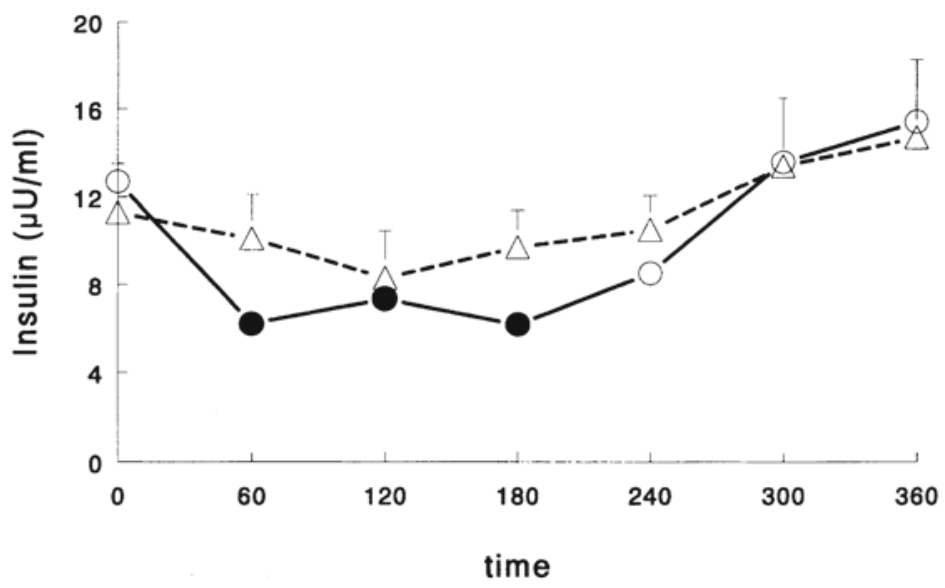

Figure 2. The plasma level of insulin in sheep subcutaneously injected with octreotide $(0.75 \mu \mathrm{g} / \mathrm{kg}$ bodyweight $)$ or saline $(0.9 \% 0.5 \mathrm{ml})$. Filled symbols represent a significant difference of at least $\mathrm{p}<0.05$ from the preinjection value. Data are given as means of 4 sheep and vertical bars represent standard error of mean. 


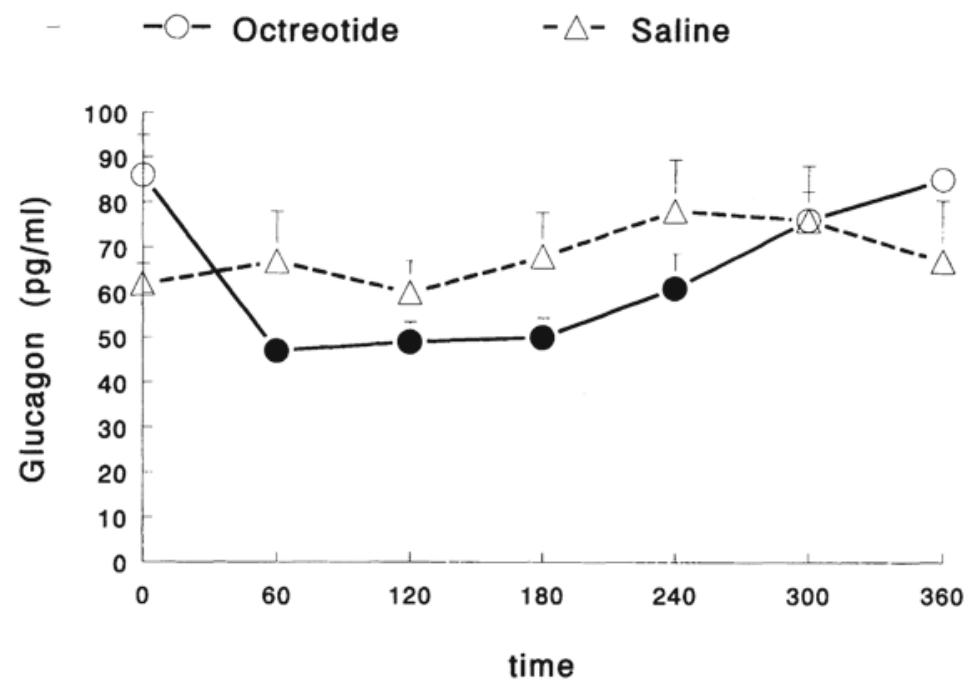

Figure 3. The plasma level of glucagon in sheep subcutaneously injected with octreotide $(0.75 \mu \mathrm{g} / \mathrm{kg}$ bodyweight $)$ or saline $(0.9 \% 0.5 \mathrm{ml})$. Filled symbols represent a significant difference of at least $\mathrm{p}<0.05$ from the preinjection value. Data are given as means of 4 sheep and vertical bars represent standard error of mean.

$$
-\bigcirc-\text { Octreotide } \quad-\triangle-\text { Saline }
$$

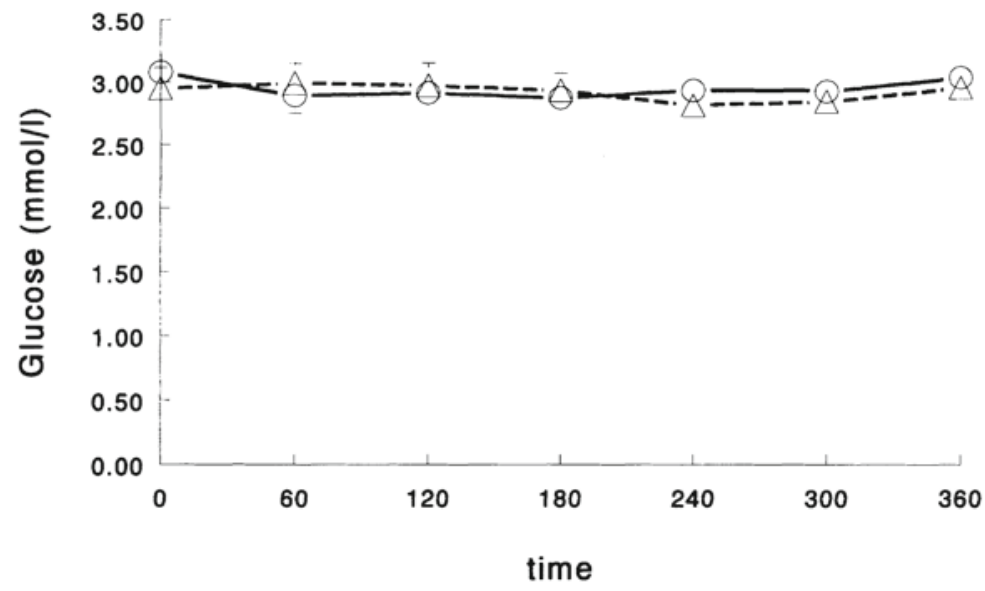

Figure 4 . The plasma level of glucose in sheep subcutaneously injected with octreotide $(0.75 \mu \mathrm{g} / \mathrm{kg}$ bodyweight) or saline $(0.9 \% 0.5 \mathrm{ml})$. Data are given as means of 4 sheep and vertical bars represent standard error of mean. 
errors. The tests for significance were done by the paired Student's t-test.

\section{Results}

The abomasal fluid $\mathrm{pH}$ was significantly elevated above the pre-injection value $1 \mathrm{~h}$ after the octreotide injection. The $\mathrm{pH}$ then declined and returned to the pre-injection value after $6 \mathrm{~h}$ (Fig. 1). When the sheep instead, as a control, were given an injection of saline, the $\mathrm{pH}$ level remained stable throughout the $6 \mathrm{~h}$ measurement period (Fig. 1).

The turnover time of abomasal fluid for the sheep was $26 \pm 1.4 \mathrm{~min}$ when they, as a control, received saline. After octreotide injection the turnover time had decreased to $56 \pm 4.7 \mathrm{~min}$ $(\mathrm{p}<0.01)$.

The plasma level of insulin had decreased significantly $1 \mathrm{~h}$ after the octreotide injection, and remained low for at least another $2 \mathrm{~h}$ (Fig. 2). Five hours post-injection the insulin level had returned to the pre-injection level again. The level of insulin did not differ significantly from the pre-injection level at any sampling event when the sheep were injected with saline.

No significant deviation from the pre-injection glucagon value was observed when the animals were injected with saline. After injection with octreotide the glucagon level decreased and the pattern showed similarities with that of insulin (Fig. 3).

The plasma glucose level did not change much during the $6 \mathrm{~h}$ measurement period for either of the 2 treatments (Fig. 4).

\section{Discussion}

Somatostatin reduces the basal plasma level of insulin and glucagon in monogastric species (see review by Arimura 1981) and sheep (Brockman \& Greer 1980, Holtenius \& Hydbring 1993). This study shows that also the long-acting somatostatin analogue octreotide can decrease the plasma level of insulin and glucagon in sheep. This appears to be the first time the effect of octreotide has been studied in a ruminant species. In the present study, both the insulin and the glucagon levels were reduced, but the plasma glucose concentration was not affected. Glucagon stimulates glucose output by accelerating hepatic gluconeogenesis and glycogenolysis, and insulin promotes the uptake and utilization of glucose by many peripheral tissues. The simultaneous decrease in insulin and glucagon in the present study most likely suppressed both the production and utilization of glucose. It has been shown that somatostatin decreases glucose production in sheep (Brockman 1979), and similar results have been reported with octreotide in man (Eriksson \& Wahren 1989). Furthermore, recent in vitro studies indicate that somatostatin also inhibits glucagon-stimulated glycogenolysis and gluconeogenesis in hepatocytes (Rosa et al. 1992). It has been suggested that ketosis in high-producing dairy cows under certain conditions is due to inhibited gluconeogenesis which suppresses the glucose available as fuel and therefore induces hyperketonemia (Holtenius 1993). It would be interesting to investigate if those cows have high levels of endogenous somatostatin.

The abomasal fluid $\mathrm{pH}$ of the sheep which got saline within the range previously reported (Hill 1965) did not fluctuate much throughout the $6 \mathrm{~h}$ measurement period. However, $1 \mathrm{~h}$ after octreotide injection, the $\mathrm{pH}$ had increased dramatically and it then decreased gradually to the pre-injection value $6 \mathrm{~h}$ after the injection. It is reasonable to assume that the increased $\mathrm{pH}$ is due to an inhibited abomasal $\mathrm{HCl}$ secretion. Exogenous somatostatin as well as octreotide can suppress gastric acid production (Arimura \& Fishback 1978, Sojka et al. 1992). Several studies indicate that som- 
atostatin has a directly inhibiting effect on the $\mathrm{HCl}$ secretion but also acts indirectly via an inhibition of the release of the $\mathrm{HCl}$ secretagogue gastrin. It has been suggested that octreotide acts in a similar way, although data on its inhibitory activity is scanty (Schally et al. 1990). Intravenous infusion of somatostatin to sheep gave rise to increased plasma concentration of gastrin in contrast to the effect on monogastric species (Barry et al. 1985). The effect of octreotide on gastrin secretion in ruminants has not yet been investigated. It is reasonable to assume that the inhibited $\mathrm{HCl}$ secretion due to the octreotide injection in the present study mainly was a direct effect on the $\mathrm{HCl}$ secretion (if octreotide has effects on gastrin release similar to those of native somatostatin).

In adult ruminants, there is a more or less continuous flow of digesta from the forestomach into the abomasum. Due to this continuous inflow, the abomasum is never empty and the presence of digesta in the abomasum causes a continuous secretion of abomasal juice (Hill 1955). Also the outflow of digesta from the abomasum is a fairly continuous process. In the present study, the rate of passage of fluid from the abomasum of saline-injected sheep corresponded rather well with those determined by Gregory \& Miller (1989). However, after octreotide injection, the turnover time of abomasal fluid was significantly retarded. In previous studies, continuous somatostatin infusion gave rise to increased mean retention time of digesta in the abomasum of adult sheep, although not as pronounced as in the present study (Barry et al. 1985). In the preruminant calf, somatostatin inhibited abomasal outflow and it was suggested that endogenous somatostatin could be involved in the regulation of abomasal function (Bell et al. 1981). The effect of somatostatin on gastric emptying has been more extensively studied in monogastric species, and it is suggested that the inhibiting effect is, at least partially, mediated by prostaglandins (Koelbel et al. 1988).

\section{Acknowledgement}

The author is grateful to Mrs. Vendula Hatasova for excellent technical assistance.

\section{References}

Aarsen $R$, Bruining G, Grose W, van Strik Lamberts $S$, Harris A: Long acting somatostatin analogue (Sandostatin) reduces late night insulinopenic ketogenesis in diabetic teenagers. Acta Endocrin. 1987, 116, suppl. 286, 45-53.

Arimura A: Recent progress in somatostatin research. Biomed. Res. 1981, 2, 233-257.

Arimura A, Fishback J: Somatostatin's regulation of secretion. Neuroendocrinology 1978, 33, 246255.

Barry T, Faichney G, Reddekop C: Gastro-intestinal function in sheep infused with somatostatin. Aust. J. Biol. Sci. 1985, 38, 393-403.

Bell F, Green A, Wass J, Webber D: Intestinal control of gastric function in the calf: The relationship of neural and endocrine factors. J. Physiol. 1981, 321, 603-610.

Brazeau P, Vale W, Burgus $R$, Ling $N$, Butcher $M$, Rivier J, Guillemin R: Hypothalamic polypeptide that inhibits the secretion of immunoreactive pituitary growth hormone. Science 1973, 179, 77 79.

Brockman R: Effect of suppression of glucagon secretion on glucose production in sheep. Can. J. Physiol. Pharmacol. 1979, 57, 848-852.

Brockman R, Greer C: Effects of somatostatin and glucagon on the utilization of propionate in glucose production in vivo in sheep. Aust. J. Biol. Sci. 1980, 33, 457-464.

Darvodelsky A, Davey M, Reid C, Titchen D, Wang $X$ : Immunochemical characterisation of somatostatin in ruminants. Regul. Peptides 1988, 20, 161-170.

Eriksson L, Wahren J: Intravenous and subcutaneous administration of a long-acting somatostatin analogue: effects on glucose metabolism and splanchnic haemodynamics in healthy subjects. Eur. J. Clin. Invest. 1989, 19, 213-219.

Gregory P, Miller S: Influence of duodenal digesta composition on abomasal outflow, motility and small intestinal transit time in sheep. J. Physiol. 1989, 413, 415-431. 
Grill W, Gutniac $M$, Roovete A, Efendic S: A stimulating effect of glucose on somatostatin release is impaired in non-insulin-dependent diabetes mellitus. J. Clin. Endocrin. Metabol. 1984, 59, 293 297.

Hill $\mathrm{K}$ : Continuous gastric secretion in the ruminant. Quart. J. Exp. Physiol. 1955, 40, 32-39.

Hill $K$ : Abomasal secretory function in sheep. In: Dougherty, R. (Ed): Physiology of digestion in the ruminant. London, Butterworths 1965, p 221230.

Holtenius K, Hydbring E: Somatostatin inhibits butyrate-induced insulin secretion in sheep. Acta vet. scand.1993, suppl. 89, 77-78.

Holtenius $P$ : Hormonal regulation related to the development of fatty liver and ketosis. Acta vet. scand. 1993, suppl. 89. 55-60.

Koelbel B, van Deventer $G$, Khawaja $S$, Mogard $M$, Walsh J, Mayer E: Somatostatin modulates cholinaergic neurotransmission in canine antral muscle. Amer. J. Physiol. 1988, 254, G201-G209.

Koerker D, Ruch W, Chideckel E, Palmer J, Goodner $C$, Ensinck J, Gale C: Somatostatin: Hypothalamic inhibitor of the endocrine pancreas. Science $1974,184,482-484$.

Lamers $C$ : Clinical and pathophysiological aspects of somatostatin and the gastrointestinal tract. Acta Endocrin. 1987, 116, suppl. 286, 19-25.

Rosa J, Rosa J, Fister V: Effects of somatostatin on glucose-stimulated glycogenolysis and gluconeogenesis in hepatocytes cultured in vitro. Acta Physiol. Scand. 1992, 146, 205-211.

Schally V, Colaluca J, Paulsen D, Carter W, Neitzschman $H$, Lafay, H, Cai R: Effect of somatostatin analogs on gastric acid secretion in dogs and rats. Int. J. Peptide Protein Res. 1990, 36, 267-274.

Schusdziarra V, Harris V, Conlon J, Arimura A, Unger R: Pancreatic and gastric somatostatin release in the response to intragastric and intraduodenal nutrients and $\mathrm{HCl}$ in the lobe. $\mathrm{J}$. clin. Invest. 1978, 62, 509-518.
Sissons J, Bell F, Girard C, Wass J: Nutrient sensitivity of gastric emptying of digesta in the preruminant calf. Br. J. Nutr. 1988, 59, 335-343.

Sojka J, Weiss J, Samuels L, You G: Effect of the somatostatin analogue octreotide on gastric fluid pH in ponies. Amer. J. vet. Res. 1992, 53, 18181821.

Svennersten K, Nelson L, Arvinder K, Uvnäs-Moberg $K$ : Milking and feeding-induced release of the gastrointestinal hormones and somatostatin in dairy cows. J. Dairy Sci. 1989, 72, 2276-2282.

Udén P, Colucci P, Van Soest P: Investigation of chromium, cerium and cobalt as markers in the digesta. Rate of passage studies. J. Sci. Food Agric. 1980, 31, 625-632.

Warner A, Stacy B: The fate of water in the rumen. A critical appraisal of the use of soluble markers. Br. J. Nutr. 1968, 22, 369-410.

Wynick D, Polak J, Bloom S: Somatostatin and its analogues in the therapy of gastrointestinal disease. Pharmacol. Ther. 1989, 41, 353-370.

\section{Sammanfattning}

Effekter av den långtidsverkande somatostatinanalogen octreotid på löpmagsfunktionen och plasmanivån av insulin och glukagon hos får.

Effekter av peptiden octreotid studerades hos făr. Peptiden är en långtidsverkande analog till hormonet somatostatin. Octreotid $(0,75 \mu \mathrm{g} / \mathrm{kg}$ kroppsvikt) injicerades subcutant, och som kontroll injicerades en $0,9 \% \mathrm{NaCl}$-lösning. Hos djur som behandlats med octreotid hämmades löpmagens syrasekretion och passagehastigheten av ingesta genom löpmagen minskade. Plasmakoncentrationen av hormonerna insulin och glukagon sjönk som en effekt av behandlingen. Signifikanta effekter av octreotidinjektionen kvarstod 3-4 timmar efter injektionen.

Resultaten är i överenstämmelse med tidigare studier av octreotid som gjorts på enkelmagade arter.

(Received February 14, 1994; accepted May 9, 1994).

Reprints may be requested from: K. Holtenius, Department of Clinical Nutrition, Faculty of Veterinary Medicine, Swedish University of Agricultural Sciences, S-750 07 Uppsala, Sweden. 
